\title{
Mauri Ora: Creating a model of practice using Indigenous Tikanga.
}

Koha mai, Koha atu

To give and receive.

\section{Introduction}

As an Adult Educator, combined creative thinking and critical thinking can often provide learners with the tools to be innovative through their practices. He Pūawai is an Adult Tertiary Teaching L5 program at Te Wānanga o Aotearoa. The course is a 20 -week program comprised of four learning modules providing skills and learning tools for facilitators, tutors or trainers teaching Adults.

I have collaborated with a tauira to extend a Kaiako perspective and tauira vision that created a model of practice and framework. The tauira were the Semester A He Pūawai program. This framework applies Ngā Takepū, Ahurutanga, Kaitiakitanga, Koha and Mauri Ora, and these principles are embedded in Adult Teaching through the delivery and learning practices at Te Wānanga o Aotearoa. Takepu is about caring for people, relationships and cultures through a holistic approach in an educational context for all learners (Pohatu \& Timata, 2008). 
I will discuss how 'Mauri' informed and balanced innovation and creative skills that enhance relationship building. Pohatu \& Pohatu (2011) refer to 'Mauri' as the formation of human relationships. Mauri emphasises the "how and why" we shape how we learn, teach and behave (p. 1).

\section{I te timatanga - In the beginning}

It all started one morning during a noho marae stay at Papatūānuku Kōkiri Marae nestled in the heart of Mangere, Tamaki Makaurau. Tauira (learners) and I were collaborating in preparation for their Mauri Ora aromatawai (assignment). We decided to write on the whiteboard one word that summed up each tauira ako (learning). We created our mission to design a He Pūawai framework to identify our teaching and learning practices collaboratively as a class. This mission has never been done before in the He Puawai learning space, and we wanted to encompass all areas of learning because this was our holistic approach to developing our framework. Using the lens of Kaupapa Māori, this framework will guide our tauira with the design, which will underpin their values and experiences that will position them at the centre of this framework (Paenga, 2010).

Ngā kupu aroha (words of love)

\begin{tabular}{|l|l|l|l|l|}
\hline Aroha & Togetherness & Help & Manaaki & Kotahitanga \\
\hline $\begin{array}{l}\text { Helping } \\
\text { Hands }\end{array}$ & Reciprocity & Kaiako & Friendships & Whanau \\
& & & & \\
\hline
\end{tabular}


Desrae Popata was the designated kaitiaki (guardian) for our project. She is currently a Tìkanga Kaiako at Te Wananga o Aotearoa and was, in this instance, a tauira for He Puāwai. Desrae's role was to take our kupu Aroha and construct a framework that would reflect each kupu. Like every superhero, there is always a partner in crime. Aaron Henare, formally a Kaiako for performing arts at Te Wananga o Āotearoa, put together drawings that reflected tauira whakaaro (thoughts/understanding). Desrae and Aaron worked together to create this inspiring framework design and describe each core part of the framework.

\section{He Pūawai}

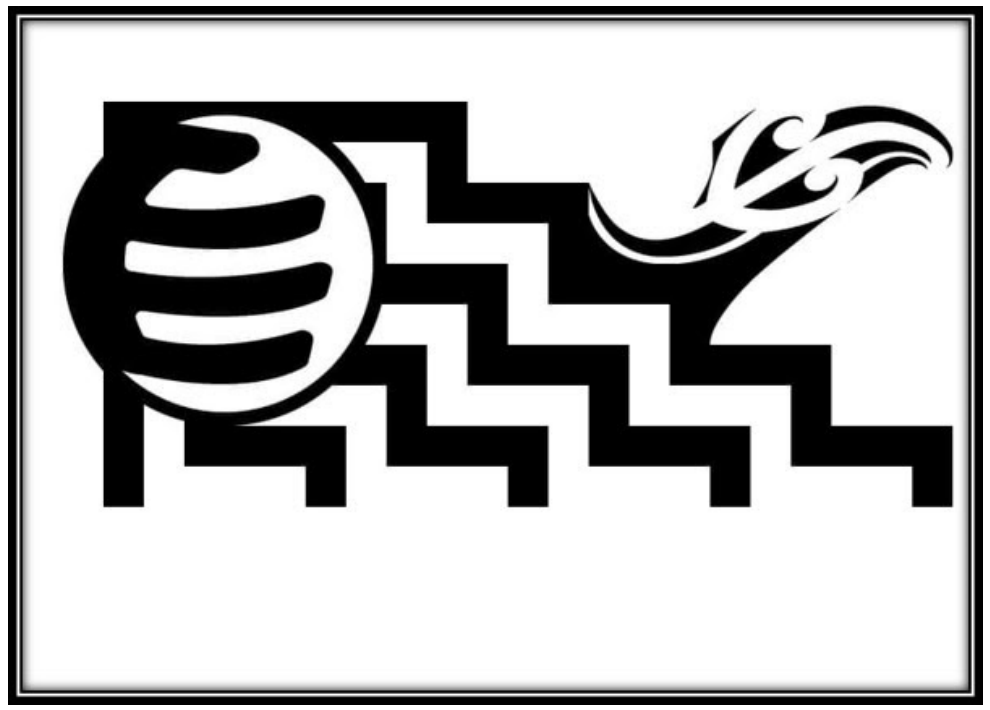

Illustrated by Aaron Henare 


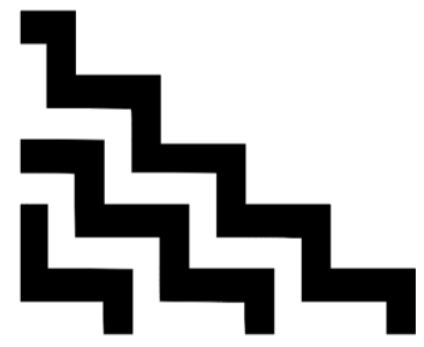

\section{Poutama}

Poutama has significant spiritual and educational meanings. The stepped pattern symbolises levels of attainment and advancement and the growth of an individual, striving ever upwards and for the betterment and sharing matauranga with those ready to listen and further their knowledge.

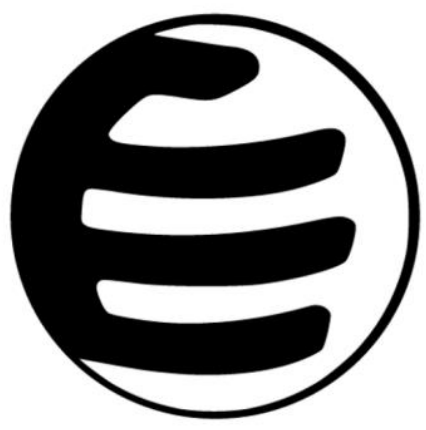

\section{Kotahitanga}

Kotahitanga is symbolic in the circle, acknowledging those worldwide from different backgrounds, ethnicities and countries and reminding them, "we are all in this together, one unit" Inside the circle is a hand that joins everyone together. Creating this safe space of Ahurutanga is crucial to bringing people together in unity as peers and, most importantly, as a whanau. 


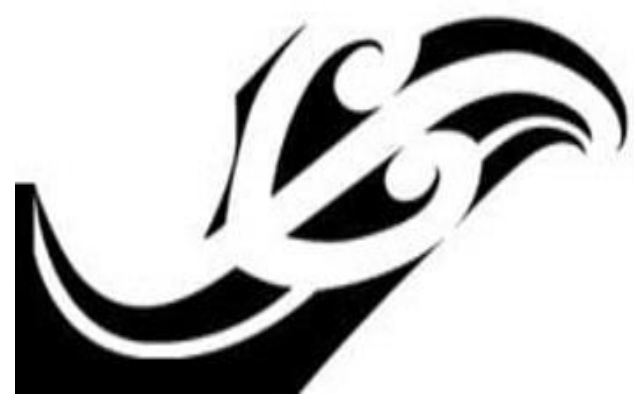

Mangopare

Mangopare design represents the reciprocity of koha mai, koha atu. To drink from the puna (pool) of knowledge and share that with

others. Being able to koha your support to help others understand with your own experiences and in return have someone do the same for you in your time of need, the ends of that design are left open purposely and represents the reciprocity and how it flows throughout the framework.

The collaboration between Kaiako and tauira using the lens of Nga Takepū created much more than a framework. We laid the foundation set for future tauira who enrol and journey in the He Pūawai program. This relationship extended well beyond the confines of a traditional classroom setting. The thought put into making this framework looked at all dimensions of learning and indigenous principles. Initially, two prototypes were made, and each design mirrored the other with the tikanga (meaning) incorporated. The final design represented all aspects of tauira visual input and encompassed their footprint infused in the design. Cultural diversity weaved into this design that promoted inclusiveness and engagement. 


\section{Koha}

Desrae created a T-Shirt design lesson plan for her practicum component of the course. Each tauira provided a blank t-shirt and heat transfer vinyl using a Cricut cutting machine and then heat pressed onto their blank t-shirts.

\section{Each tauira provided a blank t-shirt and heat transfer vinyl. Cutting their vinyl using a Cricut cutting machine and then heat pressed onto their t-shirts.}
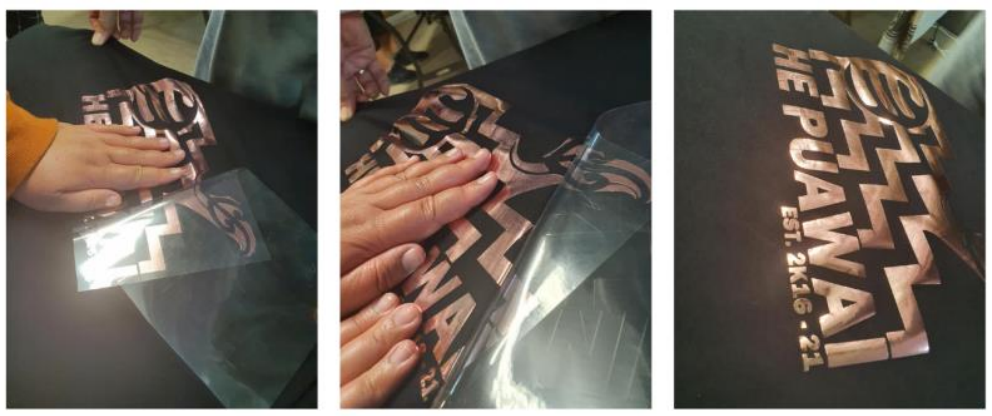

Figure 1. Cut and press

By getting Tauira involved with the cutting and pressing provided whanaungatanga (relationship building) with each other. Tauira gains a sense of belonging in their ako space. You can certainly feel something special happening with each tauira. I can liken the feeling to when children open their Christmas presents up, and their faces tell the story. I observed tauira in some form or another, and it 
was a game-changer within our program and this particular cohort. At the end of this lesson, tauira wanted to put all tops together to highlight kotahitanga. For some tauira, this was a very emotional moment. Tauira now could see that cultural values and principles were very much a part of the design for their framework. There is a connectedness that many tauira feel when learning in an indigenous learning environment. O'Malley et al. (2008) state that 'ako moments' are "snapshots of lived experiences" (p. 229). This evening was very much one of the many ako moments I have experienced as a kaiako for He Pūawai.

\section{Kotahitanga}

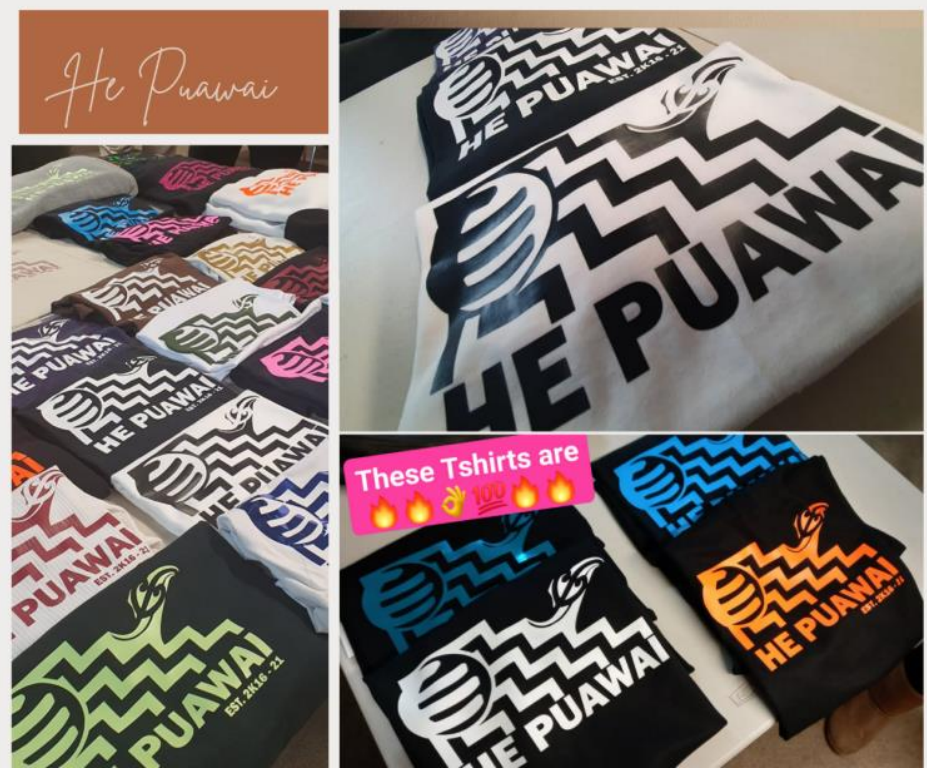

Figure 2. Kotahitanga is the final collaboration. 


\section{Reflection}

My reflective practice enables me to reshape or reform my teaching strategies. My how and why is based on my observations with tauira from the very first meeting. When you have been teaching as long as I have, you can quickly identify the personality types and learner types. Developing trust and integrity requires a mutual connection between kaiako and tauira. Founded on good working relationships between kaiako and tauira enables collaboration conducive to tauira having autonomy over their work, professional development, and identifying critical areas of support needed in their teaching space.

Frameworks and theories are proven to be valuable and transferable within any context. As I appreciate the development of the authors who constructed ideas based on a need, there is no more rewarding feeling than being part of a team that created a meaningful and purposeful framework that Semester A 2021 tauira will pass onto future tauira studying Adult Tertiary Teaching at Te Wananga o Aotearoa. It is no secret that being a kaiako in an indigenous learning space often brings some challenges. These challenges take all forms and come from all directions, but how we learn from these challenges makes us resilient to change. We acknowledge differences and embrace the diversity that empowers us as kaiako to often think outside the box. Nga mihi 2021 Semester A, He Puawai, you have shown me what koha mai, koha atu means. It means that a kaiako is only as good as her class. Ehara taku toa it te toa takitahi, engari he toa takitini.

My valour is not that of an individual but that of a multitude. 


\section{References}

O’Malley, A., Owen, J., Parkinson, D., HerangiSearancke, T., Tāmaki, M., \& Te Hira, L. (2008). Ako moments: A living culture in an educational setting. In TRADITIONAL KNOWLEDGE CONFERENCE 2008 TE TATAU POUNAMU: THE GREENSTONE DOOR (p. 226).

Paenga, M. (2010). Frameworks for Traditional Māori Knowledge Can We Talk about Traditional Māori Knowledge Without Understanding the Paradigm from Which it Originates?. In TRADITIONAL KNOWLEDGE CONFERENCE 2008 TE TATAU POUNAMU: THE GREENSTONE DOOR (p. 235).

Pohatu, T. W., \& Tìmata, H. (2008). Takepū: Principled approaches to healthy relationships. In TRADITIONAL KNOWLEDGE CONFERENCE 2008 TE TATAU POUNAMU: THE GREENSTONE DOOR (p. 241).

Pohatu, T. W., \& Pohatu, H. (2011). Mauri: Rethinking human wellbeing. Mai Review, 3, $1-12$. 